\title{
Potential distribution of the endangered endemic lizard Liolaemus lutzae Mertens, 1938 (Liolaemidae): are there other suitable areas for a geographically restricted species?
}

\author{
Winck, GR. ${ }^{a^{*}}$, Almeida-Santos, $P^{a, b}$ and Rocha, CFD. ${ }^{a}$ \\ ${ }^{a}$ Laboratório de Ecologia de Vertebrados, Departamento de Ecologia, Instituto de Biologia Roberto de A. Gomes, \\ Universidade do Estado do Rio de Janeiro - UERJ, Rua São Francisco Xavier, 524, Pavilhão Haroldo Lisboa, \\ sala 220, Bairro Maracanã, CEP 20550-013, Rio de Janeiro, RJ, Brazil \\ ${ }^{\text {b}}$ Departamento de Ecologia, Programa de Pós-graduação em Ecologia, Instituto de Biologia, Universidade Federal do Rio \\ de Janeiro, Av. Carlos Chagas Filho 373 Bl. A, Cidade Universitária, 21941-902, Rio de Janeiro, RJ, Brazil \\ *e-mail: gwinck@gmail.com
}

Received August 27, 2012 - Accepted March 18, 2013 - Distributed May 31, 2014

(With 6 figures)

\begin{abstract}
In this study we attempted to access further information on the geographical distribution of the endangered lizard Liolaemus lutzae, estimating its potential distribution through the maximum entropy algorithm. For this purpose, we related its points of occurrence with matrices of environmental variables. After examining the correlation between environmental matrices, we selected 10 for model construction. The main variables influencing the current geographic distribution of $L$. lutzae were the diurnal temperature range and altitude. The species endemism seemed to be a consequence of a reduction of the original distribution area. Alternatively, the resulting model may reflect the geographic distribution of an ancestral lineage, since the model selected areas of occurrence of the two other species of Liolaemus from Brazil (L. arambarensis and L. occipitalis), all living in sand dune habitats and having psamophilic habits. Due to the high loss rate of habitat occupied by the species, the conservation and recovery of the remaining areas affected by human actions is essential.
\end{abstract}

Keywords: lizards, coastal environment, ecological modeling, biogeography, maximum entropy.

\section{Distribuição potencial do lagarto endêmico e ameaçado Liolaemus lutzae Mertens, 1938 (Liolaemidae): existem outras áreas favoráveis a uma espécie geograficamente restrita?}

\begin{abstract}
Resumo
No presente estudo buscamos acessar informações adicionais acerca da distribuição geográfica do lagarto Liolaemus lutzae, estimando sua distribuição potencial através do algoritmo de máxima entropia. Para tanto, relacionamos os pontos de ocorrência da espécie com matrizes de variáveis ambientais. Após análise da correlação entre as matrizes ambientais, selecionamos 10 variáveis não correlacionadas para a construção do modelo. As principais variáveis que influenciam a distribuição geográfica atual de $L$. lutzae foram a amplitude média diurna de temperatura e a altitude. O endemismo atual da espécie parece ser consequência da redução da área de ocorrência original. Alternativamente, o modelo resultante pode refletir a distribuição geográfica de uma linhagem ancestral, devido à seleção das áreas de ocorrência das outras espécies de Liolaemus com registro no Brasil (L. arambarensis e L. occipitalis), todas vivendo em ambientes de dunas arenosas e possuindo hábitos psamófilos. Considerando a grande taxa de perda do habitat ocupado pela espécie, torna-se imprescindível a conservação dos remanescentes e a recuperação de áreas afetadas pelas ações humanas.
\end{abstract}

Palavras-chave: lagartos, ambiente litorâneo, modelagem ecológica, biogeografia, entropia máxima.

\section{Introduction}

Ecological modelling may be used to estimate the potential geographical distribution of species based on environmental attributes that are related to the elements necessary to allow the occurrence and distribution of a particular organism (Peterson, 2001; Guisan and Thuiller,
2005; Giovanelli et al., 2010). Different techniques for characterising the geographical distribution of species relate the occurrence records of species with environmental data, and have been widely applied in different geographical scales (Guisan and Thuiller, 2005; Phillips et al., 2006; 
Pearson et al., 2007). Applicability of such techniques include easier detection of unknown distribution areas for a species having few distributional records (Bourg et al., 2005), potential impacts of environmental changes on organisms (e.g., Rocha et al., 2009a; Sinervo et al., 2010), the support when planning conservation policies (e.g., Araújo and Williams, 2000) and to preview potential expansion in distribution of invasive alien species (e.g., Thuiller et al., 2005; Rödder et al., 2008). Species distribution modelling is commonly based substantially on climatic variables that have strong association with broad-scale geographic patterns of species richness (Hawkins et al., 2003; Buckley and Jetz, 2007). Distribution maps generated by these techniques are widely accepted among the scientific community and are increasingly being used in a range of research fields (Franklin, 2010). On the other hand, range maps generated by distribution modelling are expected to overpredict the distributional limits of species, predicting presence where it is known to be truly absent (errors of commission). This occurs because many modelling methods are unable to evaluate absences generated by evolutionary history of species, dispersal limitations, and biotic interactions with other species (Graham and Hijmans, 2006; Pineda and Lobo, 2009).

The genus Liolaemus Wiegmann, 1834 comprises more than 220 species distributed throughout South America and is known to have the greatest climatic, latitudinal and altitudinal (from sea level to over $5000 \mathrm{~m}$ ) distributions among lizards. However, only three species, all of them sand-dwellings (Etheridge, 2000), are presently known to occur in Brazil: L. arambarensis Verrastro, Veronese, Bujes and Dias-Filho, 2003 and L. occipitalis Boulenger, 1885 , both from coastal sandy habitats from southern Brazil, and Liolaemus lutzae Mertens, 1938, endemic to the restinga habitats of Rio de Janeiro State, southeastern Brazil (Rocha et al., 2005). Liolaemus lutzae is a small sand-dwelling lizard (51-80 mm snout-vent length when adult; Rocha, 1992). Its distribution is markedly narrow and comprises from Restinga da Marambaia (230.' $\mathrm{S}$,

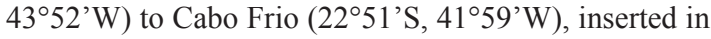
the Atlantic Rainforest domain (for details on 'restinga' environment, see Araujo and Henriques, 1984; Suguio and Tessler, 1984; Pereira and Araújo, 2000). In these areas, L. lutzae is mainly found in a thin strip of approximately 50 to $100 \mathrm{~m}$ wide of beach vegetation (Vanzolini and Ab'Saber, 1968; Rocha, 1991; Rocha et al., 2009a) where males and females share the relatively small area of habitat for their ecological tasks such as thermoregulation (Rocha, 1995), space use (Rocha, 1999) and feeding activities (Rocha, 1989). This species is currently considered to be threatened with extinction even in State level (Governmental Decree from 5 june 1998; Bergallo et al., 1998), as in federal level (Brasil, 2003) and global level (IUCN, 2012), as result of the intensive and extensive destruction of restinga habitats (Rocha et al., 2007).

In the present study, we evaluated whether Liolaemus lutzae, currently restricted to restinga areas in the state of Rio de Janeiro, would have the potential to occur in other areas of Brazil, and which bioclimatic variables would have greater influence on the limits of its distribution.

\section{Material and Methods}

We used the occurrence records of Liolaemus lutzae from Rocha et al. (2009a) (Table 1, Figure 1), excluding the population from Praia das Neves (state of Espírito Santo), due to this population resulting from an experimental introduction in the area and not within the original species distribution (see Soares and Araújo, 2008).

Table 1. Localities, municipalities and coordinates with records of Liolaemus lutzae used for potential distribution modelling. Modified from Rocha et al. (2009a).

\begin{tabular}{llll}
\hline \multicolumn{1}{c}{ Locality } & Municipality & Latitude & Longitude \\
\hline Marambaia & Rio de Janeiro & -23.049428 & -43669862 \\
Grumari & Rio de Janeiro & -23.047663 & -43.524308 \\
Recreio & Rio de Janeiro & -23.025117 & -43.457655 \\
Barra da Tijuca & Rio de Janeiro & -23.009023 & -43.348214 \\
Itaipuaçu & Maricá & -22.968892 & -42.984173 \\
Barra de Maricá & Maricá & -22.955000 & -36.773300 \\
Ponta Negra & Maricá & -22.954224 & -42.718822 \\
Jaconé & Maricá & -22.940619 & -42.668623 \\
Barra Nova & Saquarema & -22.932321 & -42.570410 \\
Itaúna/Jacarepiá & Saquarema & -22.933310 & -42.448806 \\
Pernambuca & Araruama & -22.936438 & -42.315934 \\
Massambaba & Araruama & -22.938342 & -42.283379 \\
Figueiras & Araruama & -22.944425 & -42.172768 \\
Praia Grande & Arraial do Cabo & -22.959874 & -42.047290 \\
Praia do Foguete & Cabo Frio & -22.938023 & -42.039307 \\
Praia do Forte & Cabo Frio & -22.890757 & -42.025346 \\
Praia das Conchas & Cabo Frio & -22.872014 & -41.983188 \\
Praia do Peró & Cabo Frio & -22.847097 & -41.988340 \\
\hline
\end{tabular}




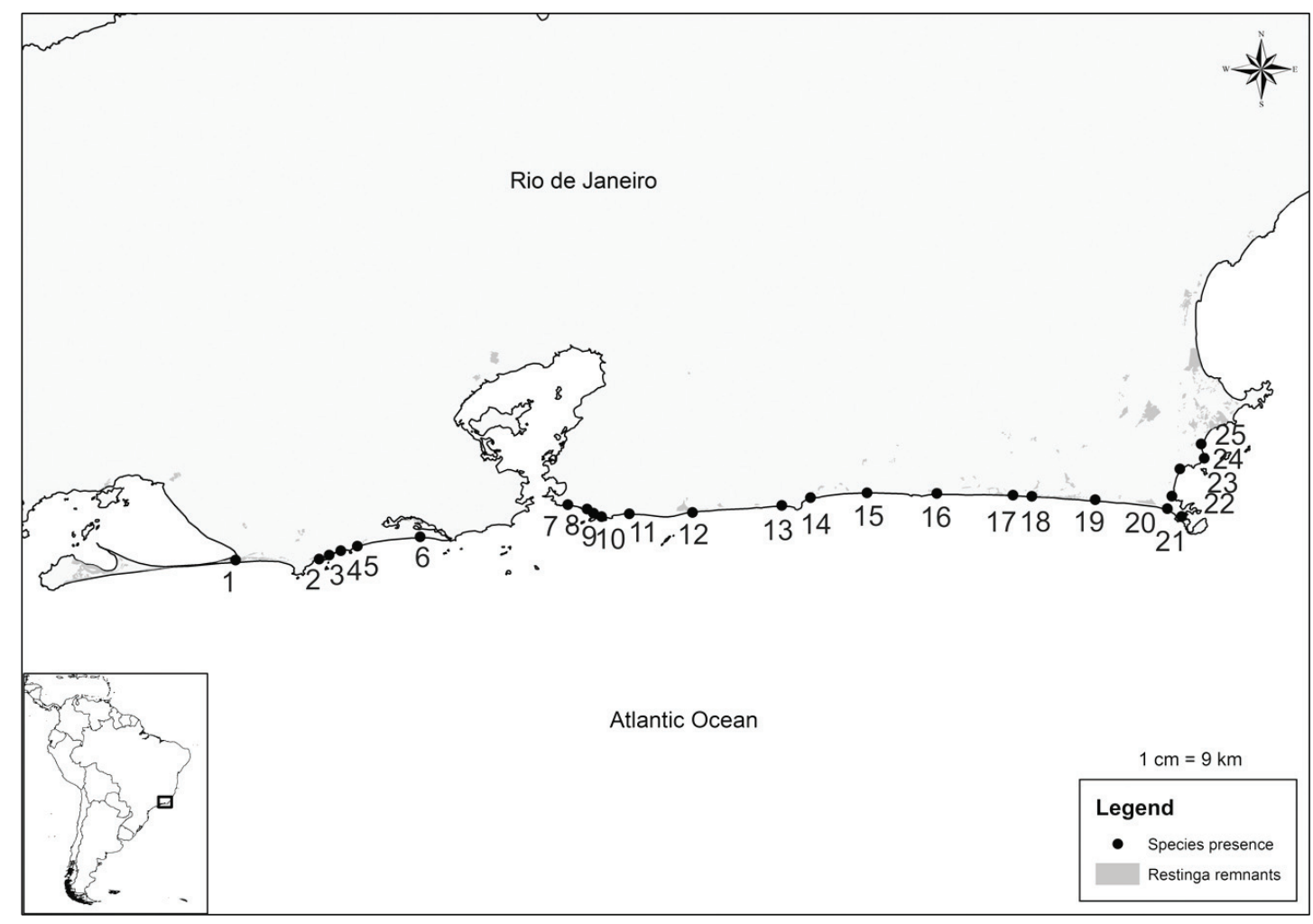

Figure 1. Records of occurrence of the lizard Liolaemus lutzae, endemic to the state of Rio de Janeiro, Brasil. Grey areas represent the remnants of restinga habitats according to the "SOS Mata Atlântica Organization". 1. Marambaia, 2. Grumari, 3. Prainha, 4. Macumba, 5. Recreio, 6. Barra da Tijuca, 7-10. Piratininga, Camboinhas, Itaipu e Itacoatiara, 11. Itaipuaçu, 12. Barra de Maricá, 13. Ponta Negra, 14. Jaconé, 15. Barra Nova, 16. Itaúna/Jacarepiá, 17. Pernambuca, 18. Massambaba, 19. Figueiras, 20. Praia Grande, 21. Praia dos Anjos, 22. Praia do Foguete, 23. Praia do Forte, 24. Praia das Conchas, 25. Praia do Peró. Modified from Rocha et al. (2009a).

To create the potential distribution model, we used the software MaxEnt 3.2.3. Despite the availability of different methods for potential distribution modelling, some studies have shown the Maximum Entropy as one of the best performing algorithms (e.g., Elith et al., 2006; Costa et al., 2010; Giovanelli et al., 2010). The model is estimated from data of presence, and generates pseudoabsence data for the calibration (Pawar et al., 2007). The maximum entropy algorithm assumes the less biased solution in the evaluation of an unknown probability of distribution, maximising its entropy (Pawar et al., 2007). The algorithm differs from the others (e.g., genetic algorithms, artificial neural networks) by building a probability distribution, while the others produce a probability for each point (see Pawar et al., 2007; Elith et al., 2011). Despite its sensibility to sampling bias, Maxent comparatively showed a better performance when sampling involve poor number of points (Costa et al., 2010).

We used 20 bioclimatic variables provided by WorldClim. org (Hijmans et al., 2005), with resolution of 30 arcseconds: annual mean temperature (bio 1); mean diurnal temperature range (bio 2); isothermality (bio 3); temperature seasonality (bio 4); maximum temperature of warmest month (bio 5); minimum temperature of coldest month (bio 6); temperature annual range (bio 7); mean temperature of wettest quarter (bio 8); mean temperature of driest quarter (bio 9); mean temperature of warmest quarter (bio 10); mean temperature of coldest quarter (bio 11); annual precipitation (bio 12); precipitation of wettest month (bio 13); precipitation of driest month (bio 14); precipitation seasonality (bio 15); precipitation of wettest quarter (bio 16); precipitation of driest quarter (bio 17); precipitation of warmest quarter (bio 18); precipitation of coldest quarter (bio 19); and altitude. Temperature data was expressed in ${ }^{\circ} \mathrm{C}$, precipitation in $\mathrm{mm}$ and altitude in meters above sea level - ASL. All matrices were than appraised in South America range. To construct the model, we used the default threshold of convergence $\left(10^{-5}\right)$ and the maximum number of data randomization (500 iterations). For manipulation of matrices and the construction of resulting maps, we used the software ArcGIS 9.3 (ESRI, 2008).

We performed a multivariate correlation test among occurrence points and all environmental variables to avoid collinearity in the model, using R (www.r-project.org). Variables with high correlation (up to $75 \%$ ) were excluded from the analysis. The Jacknife test was performed to 
evaluate which variables would be more important to the model regarding the amount of information, from two processes: the first rebuilt the model adding one variable at time; the second removes each variable. To validate and interpret the model, usually it is preferable the distinction of suitable and non-suitable areas, though the establishment of a cumulative threshold for the resulting model (presence prediction) (Pearson et al., 2007). A threshold must be defined by the user (parameter $E$ ), and consists into the amount of error associated to the presence localities dataset (see Peterson et al., 2008). However, due to the reduced geographic distribution and the well-studied populations (periodically monitored; see Rocha, 1992; Rocha and Bergallo, 1992; Rocha et al., 2009a, b), we evaluated the resulting model based in the pattern discrimination statistics (area under the curve on receiver operating characteristics; AUC and ROC, respectively). These statistics provide the evaluation that the model correctly classifies a point of actual presence and a point of true absence (Phillips et al. 2006). Values of AUC vary between zero and one, according to the proportion of hits and errors: from zero to 0.5 the discrimination is at random, and higher values indicate more hits (Elith et al., 2006). Values up to 0.75 are considered sufficiently discriminatory (Elith et al., 2006). To evaluate the importance of each environmental variable used for modelling, we used the Jacknife test, which estimates the amount of information retained by each variable in its absence and in its presence (see García, 2006).

\section{Results}

We considered 10 environmental variables in the final analysis, considered best applied among those noncorrelated, for constructing the potential distribution model for Liolaemus lutzae: mean diurnal temperature range (bio 2); isothermality (bio 3); maximum temperature of warmest month (bio 5); mean temperature of driest quarter (bio 9); precipitation seasonality (bio 15); precipitation of wettest quarter (bio 16); precipitation of driest quarter (bio 17); precipitation of warmest quarter (bio 18); precipitation of coldest quarter (bio 19); and altitude.

The model identified as the most important environmental influencing the occurrence of $L$. lutzae the diurnal temperature range ( $41.1 \%$ of contribution), precipitation of coldest quarter $(17.7 \%)$, altitude $(17.2 \%)$, maximum temperature of warmest month (11.28\%), isothermality (8.9\%), and precipitation seasonality $(3.1 \%)$. The estimation of the potential distribution suggested that this species was more likely to occur largely at sites located in coastal sand dune areas of Brazil (Figures 2-6). When compared to other species from $L$. wiegmannii group, the model for L. lutzae suggests a potential distribution in areas of currently occurrence of L. occipitalis, L. arambaraensis, L. wiegmanni, and L. multimaculatus (Figure 6). The model suggested altitude as the variable that provided the highest information gain when used in isolation, therefore holding the most useful information by itself. When the variables were removed one at a time, the diurnal temperature range decreased the gain when omitted, and therefore, retained the greatest amount of information that was absent in the other variables. AUC value for the model validation was considered satisfactory $\left(\mathrm{AUC}_{\text {model }}=0.974 \pm 0.023\right)$.

\section{Discussion}

The resulting potential distribution model of Liolaemus lutzae differs in part from the known distribution of the species (see Rocha et al., 2009a), with the current distribution being a sub-set of the area to which the species could potentially spread. Based on the model, we observe that there were sites with potential for occurrence of populations in different areas on the coast of Brazil, not only in the state of Rio de Janeiro. Probably, the environments in which the species could potentially occur have similar general environmental characteristics. Interestingly, validating the model, no inland area was predicted but instead, only areas in coastal region. This coincide to the specialized ecological requirements of the species, including thermal biology and psamophilic habits. In the state of Rio de Janeiro, beyond the northern boundary of the known distribution of $L$. lutzae, the areas with potential for occurrence of the model included restinga habitats of Jurubatiba and Grussaí. However, outside the territory of Rio de Janeiro state, both northwards and southwards, the probability of occurrence decreased considerably due to the adjustment of the model to it's distribution records. Besides those areas where the three cogeneric species live, the areas with a potential for occurrence of L. lutzae indicated by the model interestingly corresponded in part to the geographic distribution of the related lizard Tropidurus torquatus (see Rodrigues, 1987), including the restinga habitats of Jurubatiba and Grussaí. In all areas of presence of L. lutzae, T. torquatus occur sympatrically suggesting that they share similar ecological requirements. Despite the Doce River region having been recognised as an area of endemism, and potential barrier limiting taxa distributions (see Rocha, 2000; Carnaval and Moritz, 2008; Carnaval et al., 2009; Silva et al., 2012), T. torquatus manages to overcome this area. For L. lutzae, due to its limited occurrence to the narrow strip of beach areas with herbaceous vegetation, it is possible that this species could never have been able to overcome the Doce River. It is still unclear the reasons to why L. lutzae does not occur in restinga areas northwards of its northern known distribution in Rio de Janeiro state. Further detailed studies on limiting/favouring variables affecting the occurrence of this species are still needed, especially at the microhabitat and habitat scale, including sand granulation and/or dominant winds. Areas with the greatest potential for occurrence in the southern region (states of Santa Catarina and Rio Grande do Sul) correspond to the distribution of its Brazilian congeners (L. occipitalis and $L$. arambarensis), and could be reflecting the historical distribution of a common ancestor with $L$. arambarensis and $L$. occipitalis. The divergence between $L$. lutzae and L. occipitalis was previously estimated at about 4,000 years ago (Vanzolini and Ab'Saber, 1968); however, 


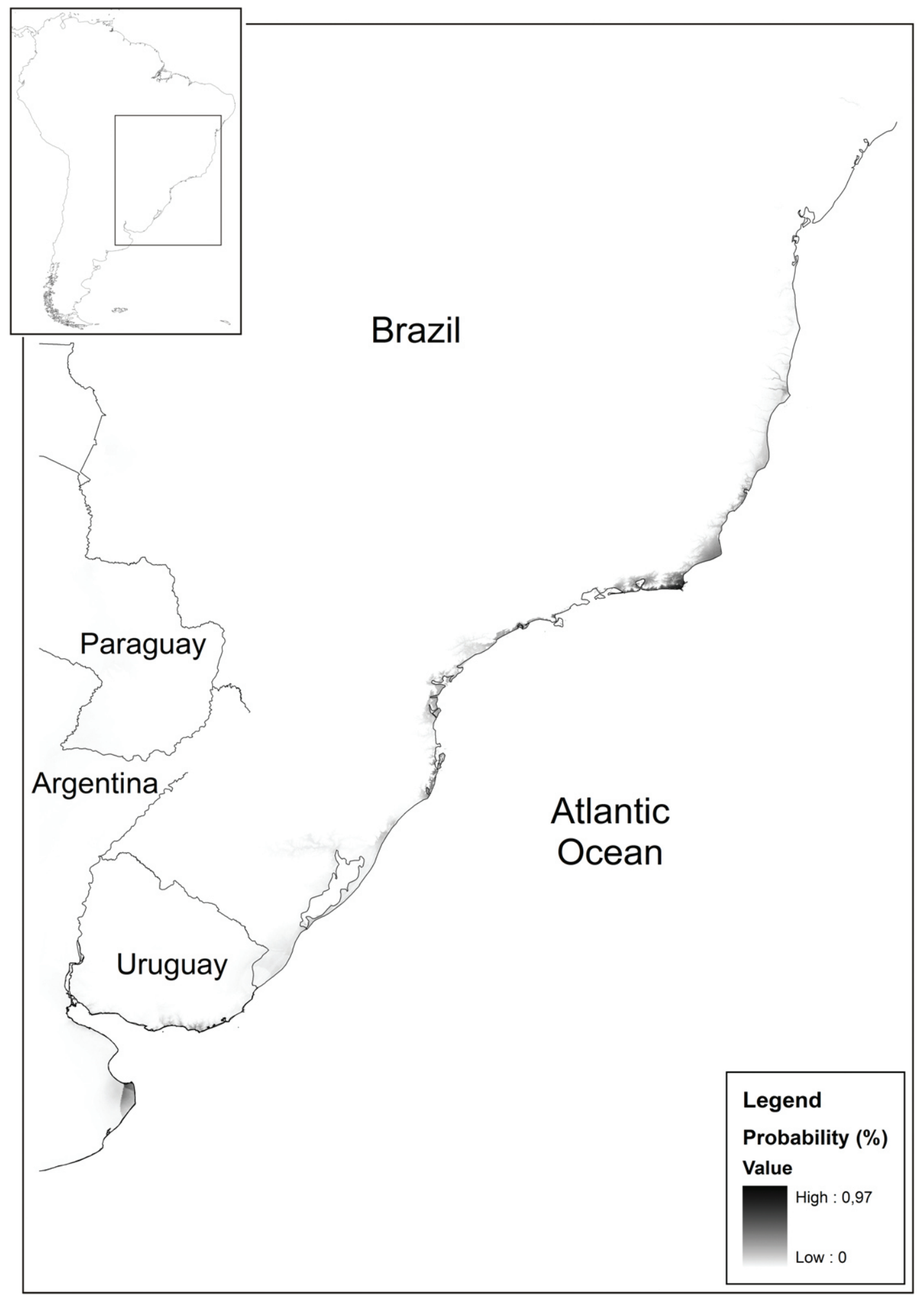

Figure 2. Map of the resulting potential distribution of Liolaemus lutzae (Squamata, Liolaemidae) in Brazil. 


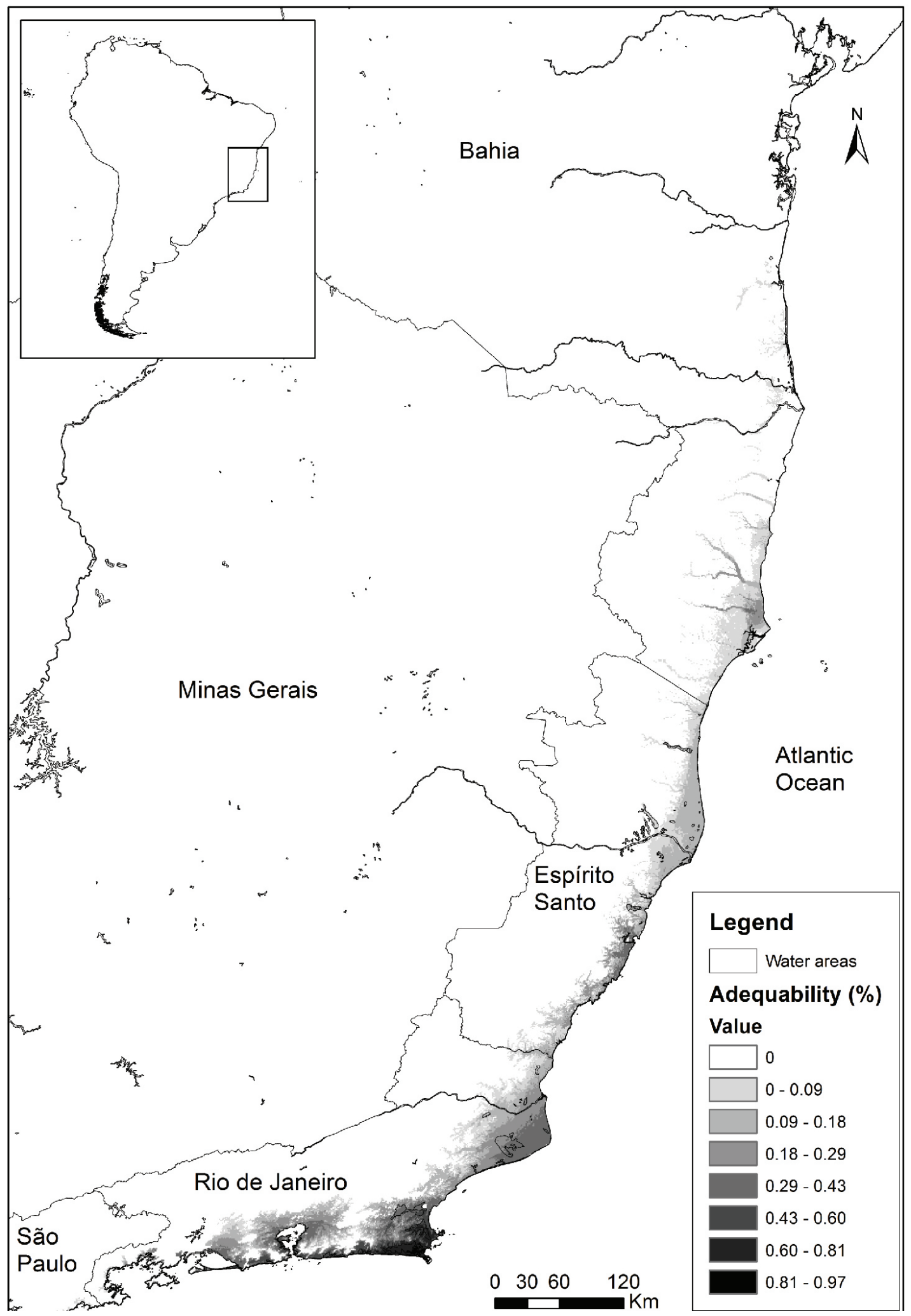

Figure 3. Map of the resulting potential distribution of Liolaemus lutzae (Squamata, Liolaemidae) in the northern portion of known geographic distribution for the species (Rio de Janeiro, Espírito Santo and southern Bahia). 


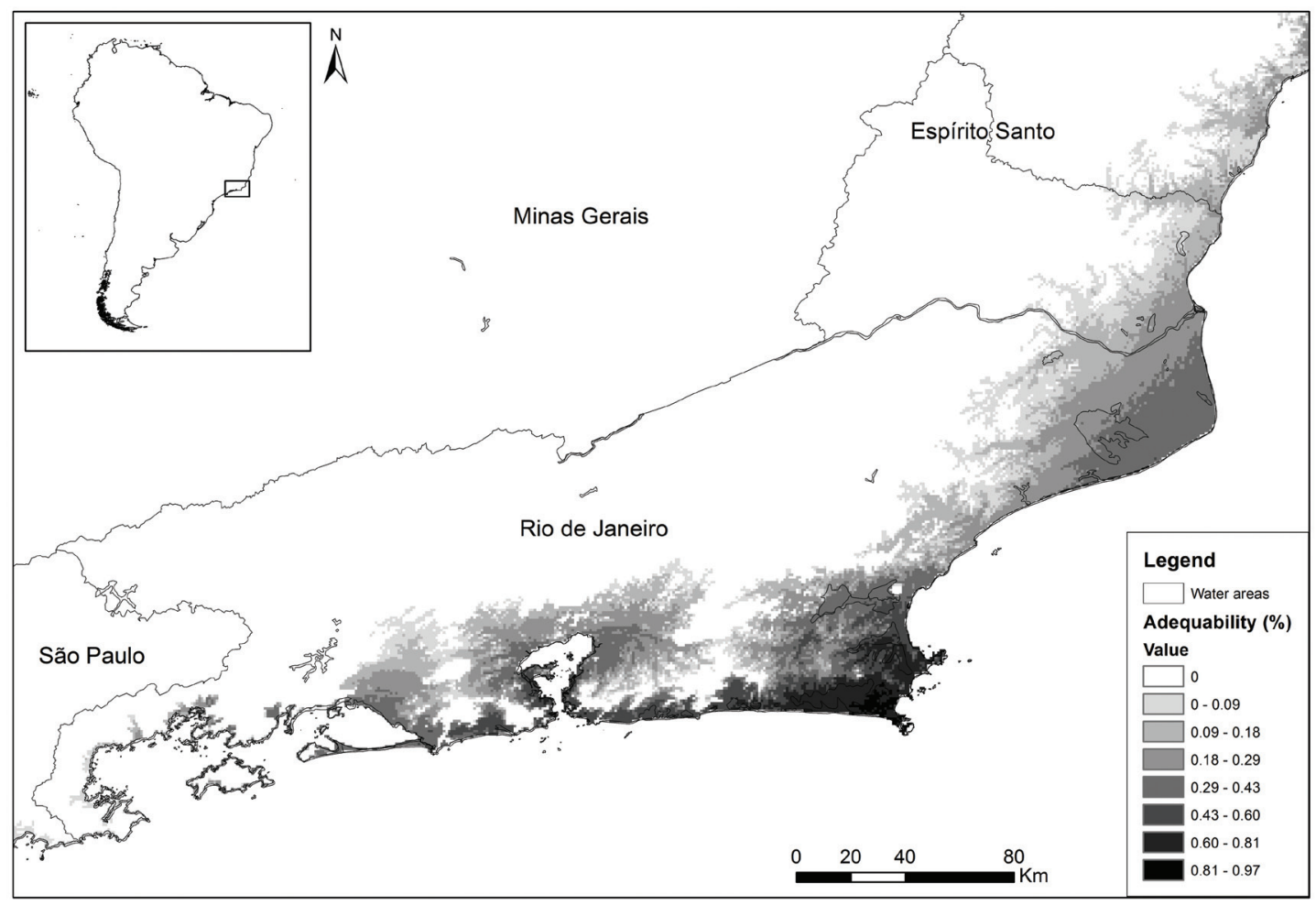

Figure 4. Resulting potential distribution of Liolaemus lutzae (Squamata, Liolaemidae) in the currently geographic distribution for the species (Rio de Janeiro). 1. Jurubatiba, 2. Grussaí.

the divergence among $L$. arambaraensis and the other two species has not yet been estimated. Suitable areas in southern São Paulo for the occupation by the species Liolaemus has been already hypothesised (Vanzolini and Ab'Saber, 1968), and these areas were also indicated by our model. Species from L. wiegmannii group are currently well distributed in subtropical zone, mainly between $24^{\circ} \mathrm{S}$ and $40^{\circ} \mathrm{S}$ (see Avila et al., 2009). The east portion of this area (which includes Brazilian territory) suffered markedly modifications on topography and climate along time, as well as intense tectonic activity (Ribeiro, 2006). Together with the Antartic cold front during late Quaternary, the region of the currently southern portion of the Atlantic Rainforest was not suitable for a forest on various periods (see Behling, 2002). The opened-vegetation habitat in subtropical region of South America may have provided the appropriate habitat for species diversification of L. wiegmannii group. On the southeastern and southern coast of Brazil, where the species of Liolaemus currently occur, the $24^{\circ} \mathrm{S}$ corresponds to middle Paraná region, previously recognised as an endemism area (see Cracraft, 1985; Silva et al., 2012). Based on vegetation modelling using palynological data, Carnaval and Moritz (2008) predicted the occurrence of forest in a longitudinal stripe, which could act as a barrier for organisms restricted to more opened environments. Liolaemus lutzae is the only species from this group that exceeds this latitudinal constraint (see Avila et al., 2009), suggesting a probably more ancient distribution from the south to at least up to the Doce River, potentially benefitting from a more open vegetation and from transgressions and regressions of the sea, followed by differentiation due to vicariance. Consequently, the divergence between L. lutzae and $L$. occipitalis may potentially be more ancient than the hypothesis of Vanzolini and Ab'Saber (1968).

The area with the greatest values for probability of occurrence of L. lutzae is adjusted to the currently known geographic distribution. This result was expected, since the maximum entropy algorithm is biased by concentration of points (see Costa et al., 2010). However, the model validation values were considered satisfactory. Further validation to the model can be provided by the low prediction value to the location of Praia das Neves as an presently area of occurrence of the species, since there was no previous occurrence of native populations previously to the deliberate intentional introduction of a set of individuals in the area which established a successfully population (see Soares and Araújo, 2008). Apparently, the large Paraiba do Sul River, which divides the states of Rio de Janeiro and Espírito Santo, may constitute an effective geographic barrier, although currently the northern known population of L. lutzae is located in Cabo Frio (Rocha, 1986; Rocha et al., 2009a).

The potential distribution of L. lutzae suggests that its occurrence would be possible in other areas of the 


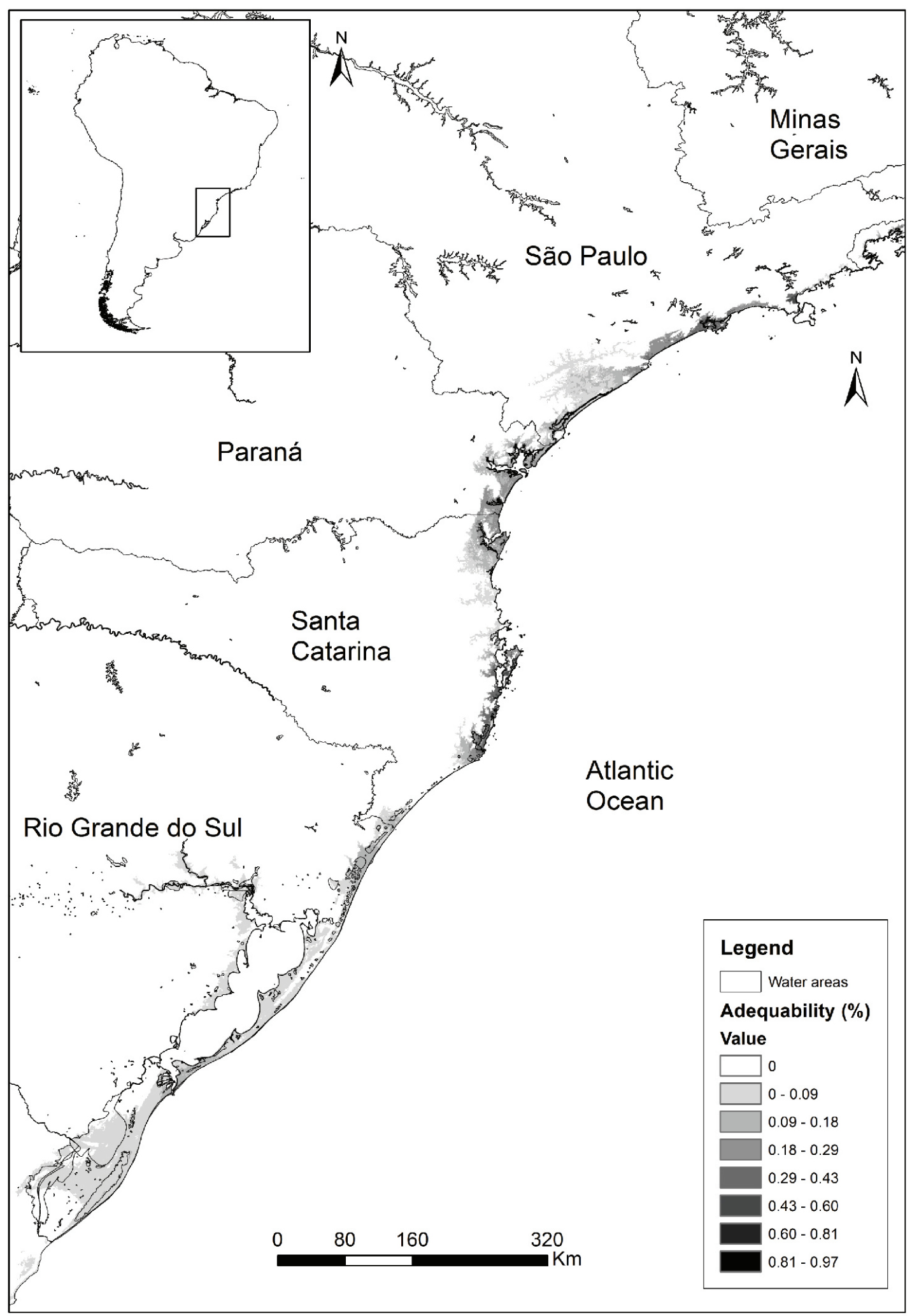

Figure 5. Map of the resulting potential distribution of Liolaemus lutzae (Squamata, Liolaemidae) in the southeasternsouthern portion of known geographic distribution for the species (São Paulo, Paraná, Santa Catarina and Rio Grande do Sul). 


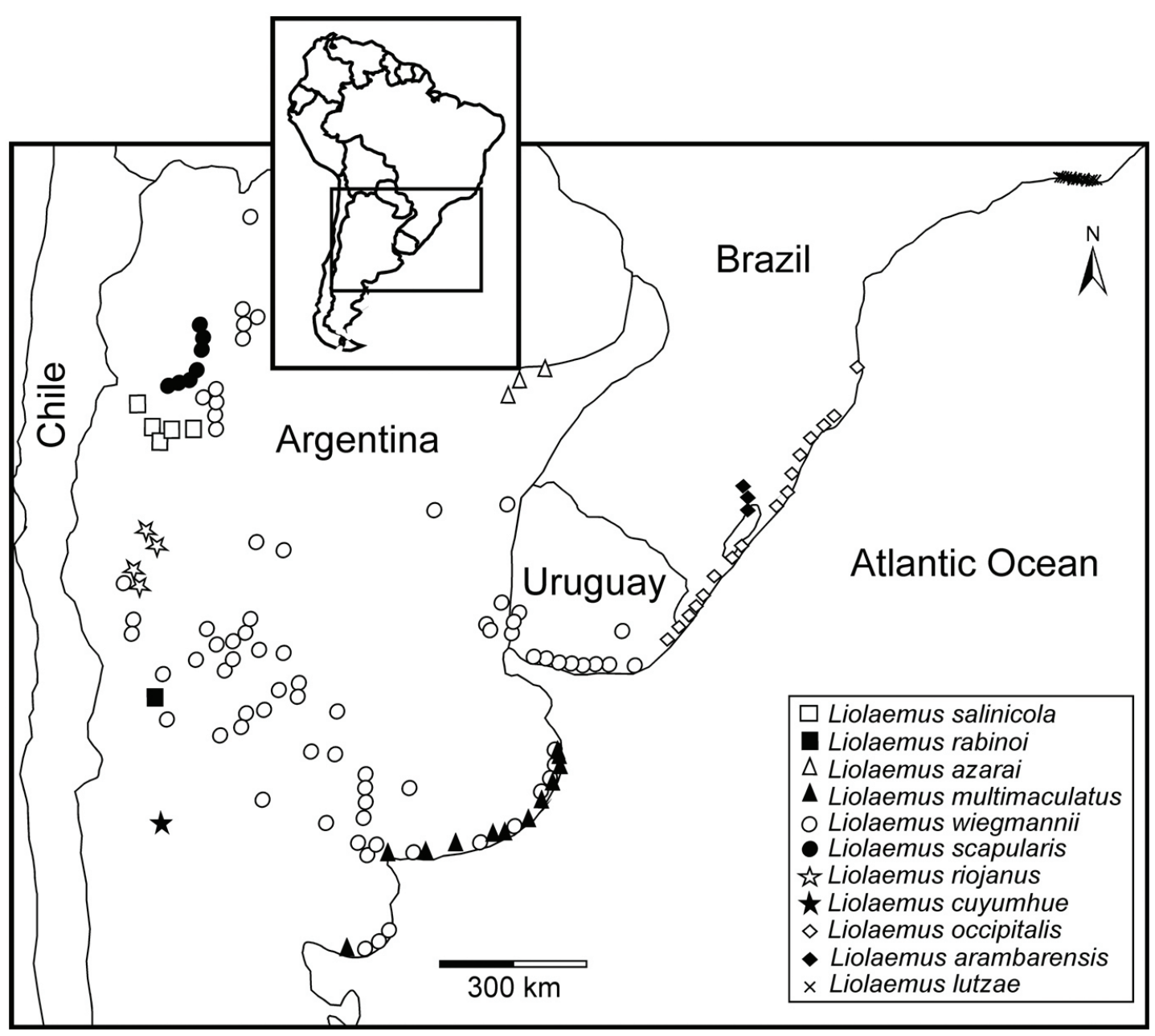

Figure 6. Distribution of the species of Liolaemus wiegmannii group. Modified from Avila et al. (2009).

Brazilian coast, considering the variables selected for this study. However, these areas are mainly located at southern coastal areas of Brazil. It is likely that L. lutzae had a greater geographic distribution historically, and that its extensive former coastal distribution area successively decreased, partly due to the sea transgressions which have suppressed extensive areas of restinga habitats along the states of Paraná, São Paulo and in the southern portion of Rio de Janeiro state.

Also, it is important to consider the human actions which can have started even during pre-colonisation and that have intensively increased throughout the last five centuries since colonisation. The elimination of some current populations (see Rocha and Bergallo, 1992; Rocha et al., 2009a) and the potential recovery when correct policies for the conservation of the species (Rocha et al., 2009b) are adopted suggest this. Alternatively, it may suggest a larger geographic distribution of an ancient lineage of the genus Liolaemus on the coast of Brazil. The conservation of restinga environments in the state of Rio de Janeiro is imperative, for the maintenance of the species, now restricted to small areas that strongly suffer ongoing human impacts.

Acknowledgements - We are grateful to the "Conselho Nacional de Desenvolvimento Científico e Tecnológico" (CNPq), which provided the Postdoctoral Research Fellowship grant to GRW (process $n^{\circ} 150855 / 2012-5$ ), and financial support to CFDR (processes $n^{\circ} 304791 / 2010-5$ and $n^{\circ} 470265 / 2010-8$ ). We also thank the Fundação Carlos Chagas Filho de Amparo à Pesquisa do Estado do Rio de Janeiro (FAPERJ) for the support to CFDR through "Programa Cientistas do Nosso Estado" (process number E-26/102.404/2009), and pos doctoral fellowship Grant at present to GRW (processnumber E-26/101.237/2013). PAS receives a scholarship fund from the "Coordenação de Aperfeiçoamento de Pessoal de Nível Superior” (CAPES). We appreciate the logistic support provided by Alberto Senra Gonçalves and Carolina Pietczak, and contributions made by Daniel Passos and the anonymous referee. 


\section{References}

ARAUJO, DSD. and HENRIQUES, RPB., 1984. Análise florística das restingas do Estado do Rio de Janeiro. In LACERDA, LD., ARAÚJO, DSD., CERQUEIRA, R. and TURCQ, B. Restingas: Origem, Estrutura e Processos Niterói: CEUFF. p. 159-194.

ARAÚJO, MB. and WILLIAMS, PH., 2000. Selecting areas for species persistence using occurrence data. Biological Conservation, vol. 96, no. 3, p. 331-345. http://dx.doi.org/10.1016/S00063207(00)00074-4.

AVILA, LJ., MORANDO, M., PEREZ DR. and SITES JUNIOR, JW., 2009. A new species of Liolaemus from Añelo sand dunes, northern Patagonia, Neuquén, Argentina, and molecular phylogenetic relationships of the Liolaemus wiegmannii species group (Squamata, Iguania, Liolaemini). Zootaxa, vol. 2234, p. 39-55.

BEHLING, H., 2002. South and southeast Brazilian grasslands during late Quaternary times: a synthesis. Palaeogeography, Palaeoclimatology, Palaeoecology, vol. 177, no. 1-2, p. 19-27. http://dx.doi.org/10.1016/S0031-0182(01)00349-2.

BERGALLO, HG., ROCHA, CFD., SLUYS, MV., ALVES, MAS., MOULTON, TP. and TANIZAKI, K. Lista da Fauna Ameaçada de Extinção do Estado do Rio de Janeiro. Diário Oficial do Estado do Rio de Janeiro, Rio de Janeiro, 05 jun. 1998, v. XXIV, p. 9-16.

BOURG, NA., MCSHEA, WJ. and GILL, DE., 2005. Putting a cart before the search: successful habitat prediction for a rare forest herb. Ecology, vol. 86, no. 10, p. 2793-2804. http://dx.doi. org/10.1890/04-1666.

BRASIL. Ministério do Meio Ambiente - MMA, 2003. Lista Nacional das Espécies da Fauna Brasileira Ameaçadas de Extinção. Brasília: MMA. 67 p.

BUCKLEY, LB. and JETZ, W., 2007. Environmental and historical constraints on global patterns of amphibian richness. Proceedings of The Royal Society/Biological Sciences, vol. 274, no. 1614, p. 1167-1173. http://dx.doi.org/10.1098/rspb.2006.0436. PMid:17327208

CARNAVAL, AC. and MORITZ, C., 2008. Historical climate modelling predicts patterns of current biodiversity in the Brazilian Atlantic forest. Journal of Biogeography, vol. 35, no. 7, p. 11871201. http://dx.doi.org/10.1111/j.1365-2699.2007.01870.x.

CARNAVAL, AC., HICKERSON, MJ., HADDAD, CF., RODRIGUES, MT. and MORITZ, C., 2009. Stability predicts genetic diversity in the Brazilian Atlantic forest hotspot. Science, vol. 323, no. 5915, p. 785-789. http://dx.doi.org/10.1126/science.1166955. PMid:19197066

COSTA, GC., NOGUEIRA, C., MACHADO, RB. and COLLI, GR., 2010. Sampling bias and the use of ecological niche modelling in conservation planning: a field evaluation in a biodiversity hotspot. Biodiversity and Conservation, vol. 19, no. 3, p. 883-899. http:// dx.doi.org/10.1007/s10531-009-9746-8.

CRACRAFT, J., 1985. Historical biogeography and patterns of differentiation within the South American avifauna: areas of endemism. Ornithological Monographs, vol. 1985, no. 36, p. 49-84. http://dx.doi.org/10.2307/40168278.

ELITH, J., GRAHAM, CH., ANDERSON, RP., DUDÍK, M., FERRIER, S., GUISAN, A., HIJMANS, RJ., HUETTMANN, F., LEATHWICK, JR., LEHMANN, A., LI, J., LOHMANN, LG., LOISELLE, BA., MANION, G., MORITZ, C., NAKAMURA, M., NAKAZAWA, Y., OVERTON, JM., PETERSON, AT., PHILLIPS, SJ., RICHARDSON, K., SCACHETTI-PEREIRA, R., SCHAPIRE, RE., SOBERÓN, J., WILLIAMS, S., WISZ, MS. and
ZIMMERMANN, NE., 2006. Novel methods improve prediction of species' distributions from occurrence data. Ecography, vol. 29 , no. 2, p. 129-151. http://dx.doi.org/10.1111/j.2006.09067590.04596.x.

ELITH, J., PHILlIPS, S., HASTIE, T., DUDÍK, M., CHEE, YE. and YATES, C., 2011. A statistical explanation of maxent for ecologists. Diversity \& Distributions, vol. 17, no. 1, p. 43-57. http://dx.doi.org/10.1111/j.1472-4642.2010.00725.x.

Environmental Systems Research Institute - ESRI, 2008. ArcGIS 9.3 Software. Redlands.

ETHERIDGE, R., 2000. A review of lizards of the Liolaemus wiegmannii group (Squamata, Iguania, Tropiduridae), and a history of morphological change in the sand-dwelling species. Herpetological Monographs, vol. 14, no. 2000, p. 293-352. http:// dx.doi.org/10.2307/1467049.

FRANKLIN, J., 2010. Moving beyond static species distribution models in support of conservation biogeography. Diversity \& Distributions, vol. 16, no. 3, p. 321-330. http://dx.doi.org/10.1111/ j.1472-4642.2010.00641.x.

GARCÍA, A., 2006. Using ecological niche modelling to identify diversity hotspots for the herpetofauna of Pacific lowlands and adjacent interior valleys of Mexico. Biological Conservation, vol. 130, no. 1, p. 25-46. http://dx.doi.org/10.1016/j.biocon.2005.11.030.

GIOVANELLI, JGR., SIQUEIRA, MF., HADDAD, CFB. and ALEXANDRINO, J., 2010. Modelling a spatially restricted distribution in the Neotropics: How the size of calibration area affects the performance of five presence-only methods. Ecological Modelling, vol. 221, no. 2, p. 215-224. http://dx.doi.org/10.1016/j. ecolmodel.2009.10.009.

GRAHAM, CH. and HIJMANS, RJ., 2006. A comparison of methods for mapping species ranges and species richness. Global Ecology and Biogeography, vol. 15, no. 6, p. 578-587. http:// dx.doi.org/10.1111/j.1466-8238.2006.00257.x.

GUISAN, A. and THUILLER, W., 2005. Predicting species distributions: offering more than simple habitat models. Ecology Letters, vol. 8, no. 9, p. 993-1009. http://dx.doi.org/10.1111/j.14610248.2005.00792.x.

HAWKINS, BA., FIELD, R., CORNELL, HV., CURRIE, DJ., GUÉGAN, JF., KAUFMAN, DM., KERR, JT., MITTELBACH, GG., OBERDORFF, T., O'BRIEN, EM., PORTER, EE. and TURNER, JRG., 2003. Energy, water, and broad-scale geographic patterns of species richness. Ecology, vol. 84, no. 12, p. $3105-$ 3117. http://dx.doi.org/10.1890/03-8006

HIJMANS, RJ., CAMERON, SE., PARRA, JL., JONES, PG. and JARVIS, A., 2005. Very high resolution interpolated climate surfaces for global land areas. International Journal of Climatology, vol. 25, no. 15, p. 1965-1978. http://dx.doi.org/10.1002/joc.1276.

International Union for Conservation of Nature and Natural Resources - IUCN, 2012. The IUCN Red List of Threatened Species. Version 2012.1. Available from: $<\mathrm{http}: / / \mathrm{www}$.iucnredlist. org>. Access in: 16 Aug. 2012.

PAWAR, S., KOO, MS., KELLEY, C., AHMED, MF., CHAUDHURI, S. and SARKAR, S., 2007. Conservation assessment and prioritization of areas in Northeast India: Priorities for amphibians and reptiles. Biological Conservation, vol. 136, no. 3, p. 346-361. http://dx.doi. org/10.1016/j.biocon.2006.12.012.

PEARSON, RG., RAXWORTHY, CJ., NAKAMURA, M. and TOWNSEND PETERSON, AT., 2007. Predicting species distributions from small numbers of occurrence records: a test case using cryptic 
geckos in Madagascar. Journal of Biogeography, vol. 34, no. 1, p. 102-117. http://dx.doi.org/10.1111/j.1365-2699.2006.01594.x.

PEREIRA, OJ. and ARAÚJO, DSD., 2000. Análise Florística das Restingas dos Estados do Espírito Santo e Rio de Janeiro. In ESTEVES F.A., LACERDA LD. Ecologia de Restingas e Lagoas Costeiras. Macaé: NUPEM/UFRJ. p. 23-61.

PETERSON, AT., 2001. Predicting species' geographic distributions based on ecological niche modelling. The Condor, vol. 103, no. 3, p. 599-605. http://dx.doi.org/10.1650/0010-5422(2001)103[0599:PS GDBO]2.0.CO;2.

PETERSON, AT., PAPES, M. and SOBERON, J., 2008. Rethinking receiver operating characteristics analysis applications in ecological niche modelling. Ecological Modelling, vol. 213, no. 1, p. 63-72. http://dx.doi.org/10.1016/j.ecolmodel.2007.11.008.

PHILLIPS, SJ., ANDERSON, RP. and SCHAPIRE, RE., 2006. Maximum entropy modelling of species geographic distributions. Ecological Modelling, vol. 190, no. 3-4, p. 231-259. http://dx.doi. org/10.1016/j.ecolmodel.2005.03.026.

PINEDA, E. and LOBO, JM. 2009. Assessing the accuracy of species distribution models to predict amphibian species richness patterns. Journal of Animal Ecology, vol. 2009, no. 78, p. 182-190.

RIBEIRO, AC. 2006. Tectonic history and the biogeography of the freshwater fishes from the coastal drainages of eastern Brazil: an example of faunal evolution associated with a divergent continental margin. Neotropical Ichthyoogy, vol. 4, no. 2, p. 225-246.

ROCHA, CFD., 1986. Distribuição geográfica de Liolaemus lutzae (Sauria: Iguanidae) um lagarto endêmico do estado do Rio de Janeiro. Boletim Fundação Brasileira Para a Conservação da Natureza, vol. 21, no. 1, p. 163-167.

-, 1989. Diet of the Brazilian sand lizard (Liolaemus lutzae) In Southeastern Brazil. Journal of Herpetology, vol. 23, no. 3, p. 292-294. http://dx.doi.org/10.2307/1564451.

-, 1991. Composição do habitat e uso do espaço por Liolaemus lutzae (Sauria: Iguanidae) em uma área de Restinga. Revista Brasileira de Biologia. Brazilian Journal of Biology, vol. 51, no. 4 , p. 839-845.

-, 1992. Reproductíve and fat body cycles of the tropical sand lizard (Liolaemus lutzae) of southeastern Brazil. Journal of Herpetology, vol. 26, no. 1, p. 17-23. http://dx.doi.org/10.2307/1565016.

-, 1995. Ecologia termal de Liolaemus lutzae (Sauria: Tropiduridae) em uma área de Restinga do Sudeste do Brasil. Revista Brasileira de Biologia. Brazilian Journal of Biology, vol. 55, no. 3, p. 481-489.

-, 1999. Home range of the tropidurid lizard Liolaemus lutzae: sexual and body size differences. Revista Brasileira de Biologia. Brazilian Journal of Biology, vol. 59, no. 1, p. 125-130.

-, 2000. Biogeografia de Répteis de Restinga: Distribuição, ocorrência e endemismos. In ESTEVES F.A., LACERDA LD. Ecologia de Restingas e Lagoas Costeiras. Macaé: NUPEM/ UFRJ. p. 99-116.

ROCHA, CFD. and BERGALLO, HG., 1992. Population decrease: the case of Liolaemus lutzae, an endemic lizard of southeastern Brazil. Ciencia e Cultura, vol. 49, no. 4, p. 269-274.

ROCHA, CFD., VAN SLUYS, M., BERGALLO, HG. and ALVES, MAS., 2005. Endemic and threatened tetrapods in the restingas of the biodiversity corridors of Serra do Mar and of the Central da Mata Atlântica in eastern Brazil. Brazilian Journal of Biology, vol. 65, no. 1, p. 159-168. http://dx.doi.org/10.1590/ S1519-69842005000100019. PMid:16025914
ROCHA, CFD., BERGALLO, HG., VAN SLUYS, M., ALVES, MAS. and JAMEL, CE., 2007. The remnants of restinga habitats in the brazilian Atlantic Forest of Rio de Janeiro state, Brazil: habitat loss and risk of disappearance. Brazilian Journal of Biology, vol. 67, no. 2, p. 263-273. http://dx.doi.org/10.1590/ S1519-69842007000200011. PMid:17876436

ROCHA, CFD., SIQUEIRA, CC. and ARIANI, CV., 2009a. The endemic and threatened Liolaemus lutzae (Squamata: Liolaemidae): current geographic distribution and areas of occurrence with estimated population densities. Zoologia (Curitiba), vol. 26, no. 3, p. 454-460. http://dx.doi.org/10.1590/S1984-46702009000300009.

ROCHA, CFD., SIQUEIRA, CC. and ARIANI, CV., 2009b. A potential recovery of a population of the sand lizard Liolaemus lutzae Mertens, 1938 in an area within its range: a lizard endemic and threatened with extinction. Brazilian Journal of Biology, vol. 69, no. 1, p. 185-187. http://dx.doi.org/10.1590/S151969842009000100024. PMid:19347163

RÖDDER, D., SOLÉ, M. and BÖHME, W., 2008. Predicting the potential distribution of two alien invasive Housegeckos (Gekkonidae: Hemidactylus frenatus, Hemidactylus mabouia). North-Western Journal of Zoology, vol. 4, p. 236-246.

RODRIGUES, MT., 1987. Sistemática, ecologia e Zoogeografia dos Tropidurus do grupo torquatus ao Sul do Rio Amazonas (Sauria, Iguanidae). Arquivos de Zoologia (São Paulo), vol. 31, no. 3, p. 105-230. http://dx.doi.org/10.11606/issn.2176-7793. v31i3p105-230.

SINERVO, B., MÉNDEZ-DE-LA-CRUZ, F., MILES, DB., HEULIN, B., BASTIAANS, E., VILLAGRÁN-SANTA CRUZ, M., LARA-RESENDIZ, R., MARTÍNEZ-MÉNDEZ, N., CALDERÓNESPINOSA, ML., MEZA-LÁZARO, RN., GADSDEN, H., AVILA, LJ., MORANDO, M., DE LA RIVA, IJ., VICTORIANO SEPULVEDA, P., ROCHA, CFD., IBARGÜENGOYTÍA, N., AGUILAR PUNTRIANO, C., MASSOT, M., LEPETZ, V., OKSANEN, TA., CHAPPLE, DG., BAUER, AM., BRANCH, WR., CLOBERT, J. and SITES, JW Jr., 2010. Erosion of lizard diversity by climate change and altered thermal niches. Science, vol. 328, no. 5980, p. 894-899. http://dx.doi.org/10.1126/science.1184695. PMid:20466932

SILVA, SM., MORAES-BARROS, N., RIBAS, CC., FERRAND, N. and MORGANTE, JS., 2012. Divide to conquer: a complex pattern of biodiversity depicted by vertebrate components in the Brazilian Atlantic Forest. Biological Journal of the Linnean Society, vol. 107, no. 1, p. 39-55.

SOARES, AHB. and ARAÚJO, AFB., 2008. Experimental introduction of Liolaemus lutzae (Squamata, Iguanidae) in Praia das Neves, State of Espírito Santo, Brazil: a descriptive study 18 years later. Revista Brasileira de Zoologia, vol. 25, no. 4, p. 640-646. http://dx.doi.org/10.1590/S0101-81752008000400009.

SUGUIO, K. and TESSLER, MG., 1984. Planícies de cordões litorâneos quaternários do Brasil: origem e nomenclatura. In LACERDA, LD., ARAÚJO, DSD., CERQUEIRA, R. and TURCQ, B. Restingas: Origem, Estrutura e Processos. Niterói: CEUFF. p. 15-26.

THUILLER, W., RICHARDSON, DM., PYSEK, P., MIDGLEY, GF., HUGHES, GO. and ROUGET, M., 2005. Niche-based modelling as a tool for predicting the risk of alien plant invasions at a global scale. Global Change Biology, vol. 11, no. 12, p. 2234-2250. http://dx.doi.org/10.1111/j.1365-2486.2005.001018.x.

VANZOLINI, PE. and AB'SABER, AN., 1968. Divergence rate in South American lizards of the genus Liolaemus (Sauria, Iguanidae). Papéis Avulsos de Zoologia, vol. 21, p. 205-208. 